UDC 378.147: 372

DOI: $10.31470 / 2415-3729-2018-8-238-251$

\title{
Formation System of Education of Ukraine and China: Comparative Analysis
}

\section{Wang Jingyi}

postgraduate student of the department of general pedagogy and pedagogy of higher education

H. S. Skovoroda Kharkiv National Pedagogical University,

$\triangle$ 2, Valentynivska Str., Kharkiv, Ukraine , 61000

E-mail: 2564610@qq.com

ORCID: 0000-0002-0740-8565

\section{Liu Chang}

postgraduate student of the department of general pedagogy and pedagogy of higher education

H. S. Skovoroda Kharkiv National Pedagogical University,

$\triangle 2$, Valentynivska Str., Kharkiv, Ukraine , 61000

E-mail: 615298842@qq.com

ORCID: 0000-0001-5934-2855

Date of receipt of the article: August 03, 2018

Article accepted for publication: November 25, 2018

\section{Формування система освіти України та Китаю: порівняльний аналіз}

\section{Ван Цзін I}

аспірант кафедри загальної педагогіки та педагогіки вищої школи, Харківський національний педагогічний університет

імені Г. С. Сковороди,

$\checkmark$ вул. Валентинівська, 2, м. Харків, Україна, 61000

\section{Лю Чан}

аспірант кафедри загальної педагогіки та педагогіки вищої школи, 
Харківський національний педагогічний університет імені Г. С. Сковороди, $\triangle$ вул. Валентинівська, 2, м. Харків, Україна, 61000

Дата надходження статті: 03 серпня 2018 р. Стаття прийнята до друку: 25 листопада 2018 р.

\section{Abstract}

The specific aspects of the education system of Ukraine and China are considered and analyzed. It is noted that the growing intellectualization of the economy is one of the important modern criteria, which is reflected in the requirements to increase the quality of education. From this point of view, the study of China's experience in the educational sector is relevant as it promotes the search for improvement of the existing educational model in Ukraine. A comparative description of the age criterion of the stages of the educational process in Ukraine and China is presented. From this point of view, there are the following links in the education system in two countries: pre-school education, elementary education, secondary education, higher education, adult education. Mechanisms for obtaining each level of education in two countries are revealed. The forms of educational institutions ownership and fees for educational services, terms of education, types of educational institutions of each level, statistics on the coverage of pre-school education, the number of children, educators and assistant educators in groups of kindergartens, pupils and teachers in classes, school regimen, grading scale, the lesson duration, the only state examination for admission to higher education, the conditions for admitting university entrants to institutions of higher education are revealed. It is also noted that there is an acute problem with the provision of teaching staff with higher education in China preschool institutions and this issue is systematically and purposefully solved by the state. The article analyzes the three top rankings of the best institutions of higher education in the world educational market in the context of the quantitative component of Ukrainian and Chinese universities representatives. The indexes for which the universities were evaluated and the world top universities' rating was created. The authors made a conclusion that only six institutions of 
higher education of Ukraine have world-class recognition, and two of them meet international standards of preparation of skilled workers. The authors based the position that China is one of the leaders in providing quality educational services, and therefore it is expedient to study the organization, content, forms and methods in the Chinese universities for the purpose of implantation of constructive experience in the educational system of Ukraine.

Key words: education, education system, Ukraine, China, analysis, educational institutions, educational services market, rating.

\section{References}

1. Top 500. (2017). Academic Ranking of World Universities 2017. Retrieved from http://www.shanghairanking.com/ARWU2017. html.

2. Academic Ranking of World Universities 2018 results announced. (2018, August 14). Retrieved from https://www. timeshighereducation.com/student/news/shanghairanking-academicranking-world-universities-2018-results-announced.

3. QS World University Rankings 2018. (2018, November 22). Retrieved from https://www.topuniversities.com/university-rankings/ world-university-rankings/2018.

4. Kadieva, D. D. (2018). Teaching of different countries. Pedagogical workshop, 1(85), 24-26.

5. Li Sian (2012). Primary School in China. Elementary School, 10, 60-61.

6. Luhovyi, V. I., Slusarenko, O. M. \& Talanova, Zh. V. (2015). Research in universities, studying in academies: the path to the integration of education and science. Pedagogy and Psychology, 4(89), 11-21.

7. Preschool Education in China. (2017, November 12). Retrieved from http://orsona.ru/2017/11/12/doshkolnoe-obrazovanie-vkitae/

8. State statistics of Ukraine. Preschool Education. (2017). Retrieved from http://www.ukrstat.gov.ua/operativ/operativ2005/osv rik/osv_u/dz_u.html.

9. Prokofiev, V. (2015). Analogues of external independent evaluation in the world. School, 11(119), 28-33. 
10. Rating of the best universities in the world according to times higher education version. (2018). Analytical Portal «Humanitarian Technologies». Retrieved from http:/gtmarket.ru/ ratings/the-world-university-rankings/info.

11. Vilchkovskyi, E. S. \& Pasichnyk, V. R. (2005). Physical education of Chinese schoolchildren. Physical education in native school, 3, 42-46.

12. Vocational school. (2017). Retrieved from https:// uk.wikipedia.org/wiki/Професійно-технічний_навчальний заклад\# cite note-1.

13. World University Rankings 2018. (2018, April 09). Retrieved from https://www.timeshighereducation.com/worlduniversity-rankings/2018/world-ranking\#!/page/22/length/50/sort_by/ rank/sort_order/asc/cols/scores.

\section{Introduction}

The state policy of Ukraine and China is aimed to the development of human capital, in particular, and the growth of the educational component. Such benchmarks are quite logical, since the growing intellectualization of the economy, one of the current criteria of the modern day, puts high-quality education that activates all countries to improve the existing educational model. It is therefore appropriate to carry out a qualitative and quantitative assessment of the educational systems of the countries that are leaders in the world market of educational services. One of these countries is China.

Among the Ukrainian scientists who carried out their scientific investigations in the context of the disclosure of modern trends in the development of education in China should be called N. Dzhgun, O. Zhernnovnykova, L. Kalashnik, N. Kotelnikova, V. Luhovyi, D. Melnychuk, N. Myronchuk, O. Slusarenko, Zh. Talanova. It should be noted that today the Chinese researchers have intensified their scientific searches on the territory of Ukraine in order to highlight the specifics of the educational process in China, as evidenced by the abstracts of candidate dissertations of Lu Shanshan, Liao Chaichzhi, Ma Baolin, Man Man, Su Siao and others.

The purpose of the article is to carry out a comparative analysis of the education systems of Ukraine and China. 


\section{Materials and Methods}

A number of scientific search methods were used for the research, in particular - analysis, synthesis, generalization and systematization of scientific literature.

\section{Results and Discussion}

The educational system of Ukraine and China is similar in its components: pre-school education; secondary education (divided into basic and profile in Ukraine, and in China incomplete and complete); vocational education (in Ukraine); Higher Education; adult education.

The first level of education is a preschool. This education is not obligatory in both countries and subordinates to the Ministry of Education. Children begin to study at a kindergarten at the age of three. The public nursery takes children from one to three years old in China, and in Ukraine - from 2 to 3 years old. Pre-school education institutions are represented in three forms of ownership: in Ukraine state, private and municipal (communal); in China - state, private and departmental.

In Ukraine, there are the following types of public nurseries: family and combined nurseries, kindergartens of compensatory type (special and sanatorium), educational complexes. In these institutions, children are included to the educational and training process. In the first younger group ( 2 or 3 years old children), the number of children is 15 . In the second / middle / older group (3-6 years old children), the number of children is 20 . However, the realities of the modern day are different: there is much larger number of children in groups, sometimes over 30 people. Provision of teaching staff is complete, higher education is desirable. Each group has one mentor and one assistant educator.

According to the State Statistics Service of Ukraine the number of pre-school establishments was 14,900 by 2017 (State statistics of Ukraine..., 2017). It should be noted that in comparison with the nineties of the twentieth century, there is a clear tendency to reduce the number of these institutions because of low birth rate. So, if in 1990 the number of pre-school establishments was 24.5 thousand, with the total number of 2428 thousand children in them, then each decade these indicators decreased, in particular in $2000-16.3$ thousand establishments and 983 thousand children; 2010 - 15.6 thousand 
establishments and 1273 thousand children; 2017 - 14,9 thousand and 1300 thousand children. The smallest number of children (968 thousand) attending pre-school establishments was in 2001, which led to their reduction or re-profiling. Today, the demographic situation is improving, as fertility has increased, but statistics shows that the number of pre-school establishments continues to decline. This leads to a situation when queues are formed to preschool educational institutions and not all children are covered by preschool education.

In China, there is a clear tendency to increase the quantitative component of pre-school educational institutions. As in Ukraine, there are not enough kindergartens in the country, and therefore not everyone has the opportunity to visit them. Number of children in the groups: younger group -25 children, middle group -30 children, older group -35 children. Standards are strictly adhered to and more than the specified limit of children in groups does not happen. There are two educators and one assistant educator in one group. However, there are not enough kindergartens, and therefore, in addition to traditional forms of preschool education, preschool groups are formed on the basis of secondary schools, institutions of additional education, centers for game support, adaptation groups etc. Children may stay in a kindergarten with overnight stay (except for two Sunday days: Wednesday and Saturday). The problem of teaching staff ensuring in pre-school institutions is acute, and therefore the state is making significant efforts to solve this problem. Higher education is a prerequisite for a teacher.

There are at least 150,000 kindergartens of different types in China today and according to the statistics only $30 \%$ of children attend children's homes (Preschool Education in China, 2017).

Secondary education institutions in the studied countries have two levels of education: primary and secondary. However, there are both common features and differences. Full secondary education is of three levels both in Ukraine (elementary education (4 years), basic secondary education (5 years), secondary education (3 years) and China (primary education (6 years), secondary education (3-4 years), full secondary education (from 2 to 4 years old)) (Vilchkovskyi, \& Pasichnyk, 2005). The form of ownership is both public and private educational institutions. The length of the school year is different, 
but the academic year begins on the first of September. The end of the academic year ends in Ukraine in the last days of May, and in China - In July. In our country school year is divided into four quarters and also there are autumn, spring holidays for about one week, winter holidays - two weeks, summer holidays - three months (June, July and August). In China, the academic year consists of two semesters lasting 9.5 months, winter holidays last from mid-January to mid-February, and summer holidays last one month in August. The training week is from Monday to Friday, beginning at 8 o'clock in both countries. However, in Ukrainian schools there are breaks between classes and the school day ends at 14 o'clock and in China at 16 o'clock with a break for an hour at a lunch time. In China, the school day is divided into two parts: in the first half, the basic subjects are studied, and in the second one - additional ones. Each class has its own training room and teachers come to classrooms, in Ukraine there is also a classroom system, but there is also an alternative a specialized classroom (when students go to a lesson to a specially equipped classroom). In China, the academic load is very high about 6-7 lessons (in high school students have 8-9 lessons), and after that students attend optional sessions, electives, hobby clubs and sports sections. At home students have many homework assignments every day, additionally go to the tutors, and on vacation they are studying all the time and solving tasks given by the teacher. Discipline is very strict in Chinese schools. Absences are recorded and if a student has skipped 12 lessons without a valid reason, he is deducted. Exams are conducted in a test version; the scale of assessment is 100-point. The duration of the lesson is 40 minutes.

In Ukraine, primary, basic and profile secondary education can be acquired either in separate or in one educational institution. In Ukrainian schools, the teaching load is based on a personoriented approach and does not take all free time at home every day. Educational subjects are distributed evenly over entire day of study during the whole academic week, pupils have 5 or 6 lessons per day (senior pupils have 6-7 lessons), and after lessons they can attend optional sessions, electives, hobby clubs or sports sections. Children receive homework for holidays, but it is not an obligatory requirement. Discipline is also strict in Ukrainian schools, but for 
absenteeism students are not deducted from the school. Exams are conducted in various forms, the scale of assessment -12 points. The duration of the lesson is 40-45 minutes.

Let's take a closer look to the second educational component the elementary school. It is compulsory and free for all citizens in both countries.

Ukrainian children attend primary school at the age of 6 or 7. The duration of training is 4 years. There are 26 or 30 pupils in the class. One teacher conducts all subjects during all years of study (except PE, Music, English, sometimes IT), and also he or she acts as a class teacher. Foreign language (usually English) is taught from the first form. Labor Education is carried out on the lessons of labor training and extracurricular activities.

Chinese children go to the elementary school at the age of six. The term of study at elementary school is 6 years. Li Sian notes that «During this period, pupils do not pay for education; they may pay only for manuals at the beginning of the year» [5]. "There are 40-45 pupils in a class in elementary school» (Vilchkovskyi, \& Pasichnyk, 2005). A class teacher and assistant teacher are assigned for each class. One teacher in China has 27.6 students (Kadieva, 2018). Learning a foreign language (mostly English) is taught from the third form. Labor Education is taught from the 4th form and lasts for two weeks every year: city schools have practice in workshops and rural schools on farms.

The next level of education is secondary. These stages have their own specifics in each country.

In Ukraine, secondary education is divided into two components: basic secondary and vocational secondary education. Basic secondary education covers 5-9 forms. After the end of the 9th form, a certificate of basic secondary education is issued. Children pass final examinations - state final certification (SFC). This level of education is free of charge.

Profile secondary education has a term of three years, after which a certificate of secondary education is issued. The student can continue his studies by choosing an academic or professional profile in one or several educational institutions: in a general education school, gymnasium, a lyceum, a training center etc. 
Another part of the Ukrainian system of education, which is specific, is secondary vocational education. It involves the training of students (three to four years) and the acquisition of their labor professions, specialties, qualifications. Also, after completing a vocational school, students receive a certificate of full secondary education. These educational institutions include: «Vocational School of the corresponding profile; vocational school of social rehabilitation; higher vocational school; vocational and artistic school; artistic vocational school; higher art vocational school; school-agribusiness; higher school-agro-firm; school-factory; vocational education center; educational and production center; Center for training and retraining of workers' personnel; training course; training center; other types of educational institutions providing vocational education» (Vocational school, 2017). Graduates of these educational institutions also have the status of full secondary education.

In China, secondary education is also divided into two levels: incomplete and complete. Children receive incomplete education at the first grade of secondary school (three or four years of study), this stage is final (the initial and incomplete education covers nine years); it is free of charge and compulsory in school education.

To complete secondary education, pupils must continue their studies by choosing a curriculum: academic or vocational. This level of education is payable. According to a sociological survey, «the cost of school education for a child in Chinese families with average wages is almost $30 \%$ of their budget» (Vilchkovskyi, \& Pasichnyk, 2005)]. Upon completion of secondary school, graduation exams are completed and graduates receive a certificate. Secondary schools of academic profile study science and prepare for admission to higher education (the duration of training is two years). It is chosen by those who plan to receive higher education.

The second profile that a pupil can choose is a professional one. Educational institutions of this profile are represented by technical schools (3 years of a training period), professional and agricultural schools (3 years) and special technical schools (training lasts for 4 years). Professional and agricultural schools are aimed to satisfy the labor market of specialists of agriculture and industrial production. More prestigious professions are received in special-technical schools, 
where the future generation of workers is trained to work in the economic, medical and legal spheres. Technical schools produce skilled workers for such sectors of the national economy as: textile, pharmaceutical, metallurgical and others.

The most prestigious level of education in both countries is higher education. If a person wants to go to study, he or she passes state exams, which is an obligatory requirement for entry into higher education institutions, as well as a certificate of full secondary education.

In Ukraine, those who have completed secondary education can continue studying at higher educational institutions. It is also necessary to pass state exams (External independent evaluation), which are held during May-June. These results are introductory examinations for higher education institutions, as well as the rating of certificates' rating. It should be noted that in Ukraine there is a possibility to receive higher education free of charge (by budget and regional order) or on a paid basis. Applicants have the right to file up to seven applications for places of budget and regional order and no more than four specialties. As for contract form of education (at the expense of individuals or legal entities) the number of applications for participation in the competition for educational places is not limited.

Chinese graduates of secondary and special technical schools can continue their studies at higher education institutions in China only on a paid basis. After graduating from a secondary school, graduates take the national exam (Gao-kao) in May. As Prof. V. Prokofiev points out: «only if you have passed this test, you can count on joining a prestigious university. It should be born in mind that graduation exams in schools are the admission exams to higher education institutions at the same time»(Prokofiev, 2015). Applicants may expect to enter a higher education institution whose category corresponds to the points received at the final examinations. Only those students who have shown outstanding abilities and those who worked in higher education before entering the university have free access to studying at higher educational institutions.

As for the recognition of higher education in the global education market, it must be admitted that at present, the level of recognition of Ukrainian higher education is very low. Gradually, 
Ukraine becomes a recipient country, while China, on the contrary, is a donor country. Modern Chinese universities create serious competition for higher education recognized leader in the global education market.

Let's give information about the ranking of the best universities in the world in recent years by the world's leading versions such as QS World University Rankings, Academic Ranking of World Universities (ARWU), Times Higher Education (THE) in the context of recognition of higher education in Ukraine and China.

QS World University Rankings ranked the following indicators: «reputation in the academic environment, citation of academic publications by university representatives, ratio of teachers and students, employer to graduate ratio, relative number of foreign teachers and students» (QS World University Rankings, 2018). The other world ranking of top universities in the world, the Academic Ranking of World Universities (ARWU), takes into account the following indicators: Nobel Prize laureates or Fields Award, Nobel Prize laureates or Fields Award, «Frequently quoted researchers in 21 categories,» articles published in Nature magazines or Science, citation indices for the natural and human sciences of the Institute of Scientific Information (ISI), Science Citation Index, and the Social Sciences Citation Index, as well as indexes of the leading journals of Arts and Humanities Citation Index, the aggregate result of previous indicators are in relation to the number of university staff $[1 ; 2]$.

The rating of the leading universities of the world from the British agency Times Higher Education (THE) takes into account the following parameters: the level of teaching, the quality of research and the volume of research citing, innovation and inclusion of the university in global international processes (Rating of the best universities..., 2018); (World University Rankings, 2018).

\section{Conclusions}

Thus, on the basis of the data inferred, we conclude that only six institutions of higher education of Ukraine have world-class recognition. Two of these meet international standards of preparation of skilled workers. The Chinese experience of developing the education system is interesting, since it considers the acceleration of civilizational changes and considers the integration processes in education and science. Therefore, it is advisable to study the practice 
of organization, content, forms and methods in Chinese universities for implantation of constructive experience in the educational model of Ukraine. Therefore, we can see the prospects for further scientific research in covering practical experience with the financing of Chinese educational institutions.

\section{Ван Цзін І, Лю Чан}

\section{Формування система освіти України та Китаю: порівняльний аналіз}

\section{Анотація}

В статті розглянуто та проаналізовано особливості системи освіти України та Китаю. Відзначається, що зростаюча інтелектуалізація економіки $€$ одним 3 важливих сучасних критеріїв, що знайшло відображення у вимогах підвищення якості освіти. 3 цієї точки зору, вивчення досвіду Китаю в освітньому секторі $€$ актуальним, оскільки сприяє пошуку вдосконалення існуючої освітньої моделі в Україні. Представлено порівняльний аналіз вікового критерію етапів освітнього процесу в Україні та Китаї. 3 цієї точки зору в системі освіти в двох країнах існують такі ланки: дошкільна освіта, початкова освіта, середня освіта, вища освіта, освіта дорослих. Виявлено механізми отримання кожного рівня освіти в двох країнах. Форми власності навчальних закладів та плата за освітні послуги, терміни навчання, типи навчальних закладів кожного рівня, статистика охоплення дошкільною освітою, кількість дітей, вихователів та помічників педагогів у групах дитячих садків, учнів та вчителі в класах, шкільний режим, шкала оцінювання, тривалість уроку, єдиний державний іспит для вступу до вищої освіти, умови для вступу до ЗВО. Відзначається також, що в Китаї існує гостра проблема з забезпеченням викладацького складу вищої освіти в дошкільних установах, i це питання систематично i цілеспрямовано вирішується державою. У статті проаналізовано три найвищі рейтинги кращих вищих навчальних закладів світового освітнього ринку в контексті кількісної складової представників українських 
та китайських університетів. Створено індекси, за якими оцінювались університети та рейтинг провідних університетів світу. Вона базується на позиції, що Китай $є$ одним 3 лідерів у наданні якісних освітніх послуг, i тому доцільно вивчати організацію, зміст, форми та методи в китайських університетах 3 метою впровадження конструктивного досвіду в систему освіти. України.

Ключові слова: освіта, система освіти, Україна, Китай, аналіз, освітні установи, ринок освітніх послуг, рейтинг.

\section{Ван Цзин И, Лю Чан}

\section{Формирование системы образования Украины и Китая: сравнительный анализ}

\section{Аннотация}

В статье рассмотрено и проанализировано специфические аспекты системы образования Украины и Китая. Отмечается, что растущая интеллектуализация экономики является одним из важных современных критериев, что отражается в требованиях к повышению качества образования. С этой точки зрения изучение китайского опыта в сфере образования является актуальным, поскольку оно способствует поиску улучшений существующей образовательной модели в Украине. Представлено сравнительное описание возрастного критерия этапов образовательного процесса в Украине и Китае. С этой точки зрения в системе образования в двух странах имеются следующие связи: дошкольное образование, начальное образование, среднее образование, высшее образование, образование для взрослых. Раскрыты механизмы получения каждого уровня образования в двух странах. Формы собственности образовательных учреждений и платы за образовательные услуги, сроки обучения, виды учебных заведений каждого уровня, статистика охвата дошкольным образованием, количество детей, воспитателей и помощников воспитателей в группах детских садов, воспитанники учителя на уроках, школьный режим, шкала оценок, продолжительность 
урока, единственный государственный экзамен для поступления в высшие учебные заведения, условия приема абитуриентов в высшие учебные заведения. Также отмечается, что в Китае существует острая проблема с обеспечением преподавательского состава высшим образованием в дошкольных учреждениях, и этот вопрос систематически и целенаправленно решается государством. В статье анализируются три топ-рейтинга лучших высших учебных заведений на мировом образовательном рынке в разрезе количественного компонента представителей украинских и китайских университетов. Индексы, по которым оценивались университеты и создавался рейтинг лучших университетов мира. Он основан на позиции, что Китай является одним из лидеров в предоставлении качественных образовательных услуг, и поэтому целесообразно изучать организацию, содержание, формы и методы в китайских университетах с целью внедрения конструктивного опыта в систему образования. Украины.

Ключевые слова: образование, система образования, Украина, Китай, анализ, образовательные учреждения, рынок образовательных услуг, рейтинг. 